\title{
Metode Drill dengan Media Scrapbook Meningkatan Konsentrasi Belajar pada Anak Retardasi Mental
}

\author{
Yuni Devi Lestari ${ }^{1}$, Fajar Surachmi ${ }^{2}$, Sugih Wijayati ${ }^{2}$ \\ ${ }^{1}$ Mahasiswa Program Studi DIV Keperawatan, Jurusan Keperawatan, Poltekkes Kemenkes Semarang \\ ${ }^{2}$ Dosen Program Studi DIV Keperawatan, Jurusan Keperawatan, Poltekkes Kemenkes Semarang \\ Corresponding author : yunidevil21@gmail.com
}

\begin{abstract}
Background: One disorder in children with mental retardation is an affective function disorder which is associated with concentration of mind. This is one of the symptoms of aberration in children developments, which makes it difficult for the child to concentrate. Therefore, an intervention is needed that triggers an increase in the concentration of learning, that is the drill method with scrapbook media.

Purpose: This research aims to determine the effect of the drill method with scrapbook media on increasing concentration in children with mental retardation in SLB-C Widya Bhakti Semarang.

Methods: This research use Pre-Experimental one group pre and post-test without control group design. The study sample was 30 mild mental retardation children in SLB-C Widya Bhakti Semarang on 4 - 12 February 2019. The sampling technique use purposive sampling and analysis of data processing use the Wilcoxon test.

Results: The results of analysis using Wilcoxon test showed p value $=0.000$ which proved that there were significant differences between before and after the treatment of the drill method with scrapbook media on increasing the concentration of learning in children with mental retardation in SLB-C Widya Bhakti Semarang.

Conclusion: It is expected that the school can provide teaching through methods and media that are more interesting and innovative so that the learning concentration of children with mental retardation can increase.
\end{abstract}

Keywords: Concentration of Study, Mental Retardation, Drill Method, Scrapbook

\section{LATAR BELAKANG}

Jumlah anak dengan retardasi mental di dunia diestimasikan antara 1-8\% dari total jumlah penduduk (Zakarya, Dewi, \& Susanto, 2016). Berdasarkan data Riset Kesehatan Dasar (Riskesdas, 2018), jumlah penyandang disabilitas di Indonesia sebesar 3,3\% dari total populasi. Sedangkan penyandang disabilitas di wilayah provinsi Jawa Tengah sebanyak 2,5\% dari total populasi. Di wilayah provinsi Jawa Tengah terdapat 6.700 anak penyandang disabilitas yang sedang menempuh pendidikan di bangku sekolah (Kemendikbud, 2017). Salah satu SLB (Sekolah Luar Biasa) di Kota Semarang yaitu SLB-C Widya Bhakti Semarang.

Salah satu gangguan pada anak dengan retardasi mental adalah gangguan pada fungsi afektif yang mana berhubungan dengan pemusatan pikiran sehingga menyebabkan anak sulit untuk berkonsentrasi. Gangguan konsentrasi merupakan salah satu gejala penyimpangan pada perkembangan anak (Fithria, 2012). Penyebab sulitnya konsentrasi 
pada anak retardasi mental adalah karena anak tersebut mempunyai keterbatasan kapasitas belajar, sulit memusatkan perhatian dan mudah lupa. Namun, anak retardasi mental dapat memusatkan perhatian pada hal-hal ataupun media yang menarik. Sedangkan untuk mengatasi masalah anak retardasi mental yang mudah lupa maka pembelajaran dapat diulang-ulang (Damayanti \& Zuhdi, 2017).

Berdasarkan pertimbangan tersebut, maka salah satu alternatif metode dan media yang dapat digunakan untuk meningkatkan konsentrasi belajar anak retardasi mental yaitu menggunakan metode drill dengan media scrapbook. Manfaat metode drill adalah dapat memberikan kesempatan pada anak untuk latihan secara berulang-ulang dalam satu kegiatan pembelajaran sehingga ketuntasan belajar dapat tercapai (Rohani \& Ahmad, 2018). Sedangkan scrapbook adalah album yang berisikan gambar dan cerita yang berkaitan dengan materi pembelajaran yang dihias dengan kreatif (Syahriyanti, dkk, 2017). Melalui penggunaan media scrapbook anak dapat menjadi lebih tertarik, aktif dan berkonsentrasi saat pembelajaran.

Berkaitan dengan penelitian terdahulu tentang penggunaan metode drill bermedia scrapbook terhadap hasil belajar siswa materi keragaman rumah adat Indonesia kelas IV sekolah dasar menyatakan bahwa ada pengaruh signifikan dari pemberian perlakuan menggunakan media scrapbook terhadap hasil belajar yang menggunakan jenis penelitian eksperimen dengan pendekatan kuantitatif (Damayanti \& Zuhdi, 2017).

Berdasarkan uraian latar belakang diatas, maka peneliti melakukan penelitian yang berjudul "Pengaruh Metode Drill Dengan Media Scrapbook Terhadap Peningkatan Konsentrasi Belajar Pada Anak Retardasi Mental di SLB-C Widya Bhakti Semarang" yang belum pernah dilakukan intervensi serupa pada penelitian sebelumnya di tempat tersebut.

\section{TUJUAN}

Mengetahui pengaruh metode drill dengan media scrapbook terhadap peningkatan konsentrasi belajar pada anak retardasi mental d SLB-C Widya Bhakti Semarang.

\section{METODE}

Penelitian ini menggunakan desain Pre-Experimental dengan rancangan One group pre and post-test without control group design. Penelitian ini hanya terdapat satu kelompok sampel yaitu anak retardasi mental ringan. Sampel penelitian ini dinilai tingkat konsentrasi belajarnya menggunakan lembar observasi konsentrasi belajar terlebih dahulu (pre test) kemudian diberikan perlakuan berupa metode drill dengan media scrapbook. Setelah diberikan perlakuan, peneliti menilai kembali tingkat konsentrasi belajar dari sampel tersebut (post test). Penelitian dilakukan pada tanggal $4-12$ Februari 2019 di SLB-C Widya Bhakti Semarang dengan jumlah responden sebanyak 30 responden.

Kriteria inklusi penelitian ini antara lain siswa dengan retardasi mental ringan, berusia 8 - 14 tahun, kooperatif dan mengikuti prosedur penelitian dari awal hingga akhir. Sedangkan kriteria eksklusi penelitian ini antara lain tidak bersedia menjadi responden, siswa yang tidak hadir pada saat penelitian, dan siswa yang telah mendapatkan intervensi serupa dengan penelitian ini. 
Instrumen yang digunakan yaitu lembar inform consent, SOP penyusunan scrapbook, scrapbook dan lembar observasi konsentrasi belajar yang sudah tervalidasi. Analisis data yang digunakan adalah Uji Wilcoxon untuk mengidentifikasi pengaruh tingkat konsentrasi belajar sebelum dan sesudah dilakukannya metode drill dengan media scrapbook.

\section{HASIL}

\section{Karakteristik Responden}

Responden pada penelitian ini terdiri dari 30 responden yaitu anak retardasi mental ringan yang berusia $8-14$ tahun. Selama jalannya penelitian, tidak ada responden yang drop out. Variabel independen penelitian ini yaitu metode drill dengan media scrapbook, sedangkan variabel dependennya adalah tingkat konsentrasi belajar pada anak retardasi mental. Karakteristik responden meliputi jenis kelamin dan usia.

Tabel 1 Karakteristik Responden Berdasarkan Jenis Kelamin ( $n=30)$

\begin{tabular}{ccc}
\hline Jenis Kelamin & $f$ & $\%$ \\
\hline Laki-laki & 20 & $66.7 \%$ \\
Perempuan & 10 & $33.3 \%$ \\
\hline
\end{tabular}

Berdasarkan Tabel 1, didapatkan hasil sebagian besar responden berjenis kelamin lakilaki yaitu sebanyak 20 orang $(66.7 \%)$, sedangkan perempuan sebanyak 10 orang $(33.3 \%)$.

Tabel 2 Karakteristik Responden Berdasarkan Usia $(n=30)$

\begin{tabular}{ccc}
\hline Usia & $f$ & $\%$ \\
\hline $8-11$ tahun & 16 & $53.3 \%$ \\
$12-14$ tahun & 14 & $46.7 \%$ \\
\hline
\end{tabular}

Berdasarkan Tabel 2, didapatkan hasil bahwa sebagian besar responden berusia dalam rentang $8-11$ tahun yaitu sebanyak 16 orang (53.3\%), sedangkan berusia dalam rentang $12-14$ tahun sebanyak 14 orang $(46.7 \%)$.

\section{Gambaran Tingkat Konsentrasi Sebelum dan Sesudah Intervensi}

Tabel 3 Tingkat Konsentrasi Belajar Anak Retardasi Mental Sebelum Dilakukan Intervensi $(n=30)$

\begin{tabular}{ccc}
\hline Konsentrasi Belajar & $f$ & $\%$ \\
\hline $0-4$ & 4 & $13.3 \%$ \\
$5-9$ & 15 & $50 \%$ \\
$10-19$ & 11 & $36.7 \%$ \\
\hline
\end{tabular}

Berdasarkan Tabel 3, didapatkan hasil bahwa skor tingkat konsentrasi belajar pada anak retardasi mental sebelum dilakukan metode drill dengan media scrapbook yaitu dengan 
skor 0 - 4 (kurang) sebanyak 4 orang (13.3\%), skor 5 - 9 (cukup) sebanyak 15 orang (50\%) dan skor 10 - 19 (baik) sebanyak 11 orang (36.7\%).

Tabel 4 Tingkat Konsentrasi Belajar Anak Retardasi Mental Sesudah Dilakukan Intervensi $(n=30)$

\begin{tabular}{ccc}
\hline Konsentrasi Belajar & $f$ & $\%$ \\
\hline $5-9$ & 3 & $10 \%$ \\
$10-19$ & 27 & $90 \%$ \\
\hline
\end{tabular}

Berdasarkan Tabel 4, didapatkan hasil bahwa skor tingkat konsentrasi belajar pada anak retardasi mental sesudah dilakukan metode drill dengan media scrapbook yaitu dengan skor 5 - 9 (cukup) sebanyak 3 orang (10\%) dan skor $10-19$ (baik) sebanyak 27 ornag $(90 \%)$.

\section{Analisa Pengaruh Metode Drill dengan Scrapbook terhadap Tingkat Konsentrasi}

Tabel 5 Hasil Uji Wilcoxon Perbedaan Tingkat Konsentrasi Belajar Anak Retardasi Mental Sebelum dan Sesudah Dilakukan Intervensi $(n=30)$

\begin{tabular}{ccc}
\hline Konsentrasi Belajar & Mean \pm SD & $p$ value \\
\hline Sebelum & $8.30 \pm 3.602$ & \multirow{2}{*}{0.001} \\
Sesudah & $13.93 \pm 3.393$ & \\
\hline
\end{tabular}

Berdasarkan Tabel 5, diketahui bahwa terdapat perbedaan skor tingkat konsentrasi belajar pada anak retardasi mental sebelum dan sesudah dilakukan metode drill dengan media scrapbook dibuktikan dengan $p$ value $<0.05(p=0.000)$.

\section{PEMBAHASAN}

Karakteristik responden berdasarkan jenis kelamin dalam penelitian ini menunjukkan sebagian besar responden berjenis kelamin laki-laki. Menurut O'Brien (2013) sebagian besar penderita yang mengalami retardasi mental yaitu berjenis kelamin laki-laki. Kelebihan kromosom $\mathrm{X}$ yaitu fragile $X$ syndrome menjadi penyebab yang menimbulkan pengaruh tidak baik pada kesehatan jiwa, timbulnya psikosis, gangguan tingkah laku dan kriminalitas. Laki-laki yang hanya memiliki satu kromosom $\mathrm{X}$ akan berdampak lebih parah dibanding perempuan yang memiliki dua kromosom $\mathrm{X}$.

Hal ini sejalan dengan penelitian yang dilakukan oleh Wardhani (2015) yang menunjukkan bahwa jumlah penderita retardasi mental paling banyak dengan jenis kelamin laki-laki yaitu sebesar $66.7 \%(n=21)$. Begitu pula hasil penelitian dari Merdekawati \& Dasuki (2017) yang menunjukkan bahwa jenis kelamin laki-laki lebih banyak daripada jenis kelamin perempuan dengan persentase laki-laki $60 \%$ dengan jumlah responden sebanyak 125 orang. Hasil penelitian lainnya oleh Sartika (2017) menunjukkan bahwa dari 46 orang responden sebanyak $60.9 \%$ berjenis kelamin lakilaki dan sebanyak $39.1 \%$ berjenis kelamin perempuan.

Seperti pada penelitian yang telah saya lakukan di SLB-C Widya Bhakti Semarang, para responden yang berjenis kelamin laki-laki terlihat lebih sulit diatur, seringkali gaduh 
sendiri, sering melontarkan banyak perkataan dengan nada tinggi dan cenderung mencari perhatian. Sama halnya seperti penelitian oleh Ramayumi, Nurdin, \& Nurhajjah (2014) yang mengatakan bahwa responden laki-laki lebih memiliki hiperaktifitas yang tinggi, sedangkan perempuan lebih bersikap diam dan pasif sehingga responden lakilaki lebih kesulitan dalam memfokuskan perhatian.

Karakteristik responden berdasarkan usia dalam penelitian ini menunjukkan sebagian besar responden berusia 8-11 tahun. Menurut Departemen Kesehatan (2009) usia tersebut termasuk dalam kategori usia anak. Menurut Merdekawati \& Dasuki (2017) kejadian retardasi mental paling sering terjadi pada anak usia sekolah dengan angka yang lebih rendah pada periode pra sekolah, mereka tidak lagi mengalami retardasi mental pada akhir masa remaja. Hal ini dikarenakan dalam tahapan perkembangan anak retardasi mental usia dibawah 12 tahun, anak belum mampu menguasai ide secara abstrak namun anak sudah dapat berfikir logis mengenai peristiwa kongkrit serta dapat mengelompokkan sesuatu ke dalam bentuk yang berbeda (Damayanti \& Zuhdi, 2017).

Penelitian ini sesuai dengan penelitian oleh Sartika (2017) yang menunjukkan bahwa dalam penelitiannya jumlah responden berusia 5 - 11 tahun sebanyak 22 orang (47.8\%), responden berusia $12-17$ tahun sebanyak 17 orang (37\%) dan responden berusia 18 25 tahun sebanyak 7 orang (7\%). Dari hasil tersebut terlihat bahwa responden paling banyak berusia dibawah 12 tahun.

Mayoritas responden pada penelitian ini masuk dalam kategori usia anak yaitu usia 8 11 tahun dimana pada usia tersebut anak masih perlu bantuan dan bimbingan dalam pengembangan kemampuan khususnya dalam memusatkan perhatian dan konsentrasi belajar pada anak retardasi mental.

Hasil penelitian yang dilakukan di SLB-C Widya Bhakti Semarang terhadap 30 responden, didapatkan frekuensi skor tingkat konsentrasi belajar sebelum diberikan perlakuan yaitu sebanyak 4 responden (13.3\%) memiliki tingkat konsentrasi kurang, sebanyak 15 responden (50\%) memiliki tingkat konsentrasi cukup dan sebanyak 11 responden $(36.7 \%)$ memiliki tingkat konsentrasi baik.

Menurut Setyaningsih (2017) konsentrasi belajar merupakan kemampuan memusatkan perhatian pada proses belajar dimana dalam memahami isi bahan ajar diperlukan suatu atensi atau perhatian yang kuat. Salah satu faktor yang mempengaruhi konsentrasi belajar yaitu faktor psikologis yang dapat mempengaruhi intelegensi dan perhatian. Faktor tersebut dapat mempengaruhi bagaimana sikap dan perilaku siswa dalam berkonsentrasi, misalnya karena adanya masalah dalam lingkungan sekitar dan keluarga. Hal seperti itu tentunya akan mempengaruhi psikologis siswa, karena siswa akan kehilangan semangat dan motivasi belajar mereka, yang tentunya berpengaruh juga terhadap tingkat konsentrasi yang semakin menurun. Kondisi psikologis lain seperti Intelligence Quotient (IQ) yang rendah juga dapat membentuk pola pikir yang rendah serta kemampuan dalam konsentrasi yang lemah. Seperti penelitian sebelumnya yang menyatakan bahwa anak retardasi mental sering mengalami gangguan berupa mudah beralihnya perhatian dan kurang konsentrasi (Elly, 2013). 
Pada penelitian ini, mayoritas penderita retardasi mental memiliki tingkat konsentrasi belajar yang cukup. Hal ini berkaitan dengan penyebab retardasi mental yang mengalami gangguan pada susunan saraf pusat, kemampuan berfikir yang rendah, perhatian yang lemah serta konsentrasi yang mudah beralih sehingga menyebabkan anak mengalami kesulitan mengikuti pelajaran yang diberikan. Seperti penelitian oleh Sari \& Eklesia (2018) yang mengatakan bahwa gangguan saraf pusat dapat mempengaruhi pada semua gerakan motorik atau aktivitas yang dilakukan.

Tingkat konsentrasi belajar setelah dilakukan metode drill dengan media scrapbook yaitu sebanyak 3 responden (10\%) dengan konsentrasi belajar cukup dan sebanyak 27 responden (90\%) dengan konsentrasi belajar baik. Metode drill merupakan suatu cara mengajar dimana siswa melaksanakan kegiatan latihan secara terus-menerus sehingga siswa memiliki keterampilan yang lebih tinggi (Sobah, Suherman, \& Wiharna, 2017). Bersamaan dengan pemberian latihan secara terus menerus, penggunaan media yang tepat juga dapat membantu siswa untuk cepat memahami materi pembelajaran khususnya anak retardasi mental. Hal ini bisa berdampak pada perbaikan fungsi kognitif yaitu peningkatan proses berfikir persepsi, ingatan, pengembangan ide dan penilaian penalaran, sehingga sangat baik diterapkan untuk anak yang kurang mampu berkonsentrasi seperti anak retardasi mental.

Setelah dilakukan intervensi metode drill dengan media scrapbook, tingkat konsentrasi pada anak retardasi mental meningkat dilihat dari karakteristik anak yang lebih tenang dan cepat menyelesaikan susunan scrapbook sebelum waktu yang telah ditentukan berakhir sehingga suasana dan kondisi saat pembelajaran lebih kondusif serta anak cenderung lebih mudah diatur.

Hasil penelitian menunjukkan nilai mean sebelum dilakukan metode drill dengan media scrapbook adalah 8.30 dengan standar deviasi 3.602 dan nilai mean setelah dilakukan metode drill dengan media scrapbook adalah 13.93 dengan standar deviasi 3.393. Sedangkan dengan menggunakan uji Wilcoxon menunjukkan bahwa nilai $p$ value 0.000 .

Metode drill merupakan suatu cara mengajar dimana siswa melaksanakan kegiatan latihan secara terus-menerus sehingga siswa memiliki keterampilan yang lebih tinggi dimana metode pembelajaran ini mampu mengatasai kesulitan belajar (Sobah, Suherman, \& Wiharna, 2017). Media scrapbook merupakan salah satu media untuk meningkatkan konsentrasi belajar dikarenakan sesuai dengan kemampuan belajar anak retardasi mental yang lamban sehingga membutuhkan pengulangan (drill) dan karakteristik gaya belajar visual yang dimiliki dimana mereka lebih tertarik dengan segala sesuatu yang menarik perhatian karena terkait dengan adanya gangguan kesulitan memfokuskan perhatian.

Penelitian yang terkait dengan penelitian ini adalah penelitian oleh Rohani dan Ahmad (2018) yang menunjukkan bahwa ada pengaruh yang signifikan dari pemberian perlakuan yang berupa penggunaan media scrapbook terhadap hasil belajar dengan mean pre test sebesar 35.93 dan post test sebesar 75.93 .

Penyusunan scrapbook secara berulang-ulang yang telah dilakukan membentuk adanya proses interaksi psikososial dua arah antara peneliti dan responden untuk meningkatkan 
faktor pendukung, pendorong dan melatih responden untuk meningkatkan kebiasaan dan motivasi sehingga perubahan dalam kebiasaan belajar dapat membaik dan konsentrasi belajar yang baik tersebut dapat meningkatkan pula hasil belajar.

Perbedaan tingkat konsentrasi belajar pada penelitian ini dipengaruhi oleh latihan yang dilakukan secara terus menerus atau drill dimana terjadi peningkatan mood, terbentuknya kebiasaan belajar dengan menggunakan media yang lebih menarik dan inovatif sehingga responden dapat berpacu dan tertarik untuk mengeksplorasikan perasaannya melalui media scrapbook.

\section{SIMPULAN DAN SARAN}

\section{Simpulan}

Berdasarkan hasil penelitian yang telah dilakukan pada tanggal 4-12 Februari 2019 tentang Pengaruh Metode Drill Dengan Media Scrapbook Terhadap Peningkatan Konsentrasi Belajar Pada Anak Retardasi Mental. Dapat disimpulkan ada pengaruh metode drill dengan media scrapbook terhadap peningkatan konsentrasi belajar pada anak retardasi mental $(p$ value $=0.000)$.

\section{Saran}

Diharapkan SLB dapat menerapkan metode Drill dengan media Scrapbook sesuai dengan prosedur.

\section{UCAPAN TERIMA KASIH}

Peneliti mengucapkan banyak terima kasih kepada pihak-pihak yang telah bekerja sama dan membantu dalam penyusunan karya ilmiah ini. Utamanya kepada institusi Poltekkes Kemenkes Semarang, orang tua dan SLB-C Widya Bhakti Semarang yang telah membantu penuh dalam proses penelitian.

\section{REFERENSI}

Agustini, \& Sudhana, H. (2014). Pengaruh pemberian aromaterapi terhadap konsentrasi siswa kelas $\mathrm{V}$ sekolah dasar dalam mengerjakan soal ulangan umum. Jurnal Psikologi Udayana, 1(2), 271-278. Retrieved from yanthiarya@ gmail.com

Alfiyana, R., Sukaesih, S., \& Setiati, N. (2018). Pengaruh model ARCS (Attention, Relevance, Confidence, Satisfaction) dengan metode talking stick terhadap motivasi dan hasil belajar siswa materi sistem pencernaan makanan. Journal of Biology Education, 7(2), 226-236. Retrieved from http://journal.unnes.ac.id/sju/index.php/ujbe

Aziz, S. (2014). Pendidikan seks bagi anak berkebutuhan khusus. Jurnal Kependidikan, II(2), 182-204. https://doi.org/10.1192/bjp.205.1.76a

Bader, J. L. (2005). The effects of a scrapbooking project on student self-concept in an inclusive setting. State University of New York. Retrieved from http:digitalcommons.brockport.edu/ehd_theses/430

Damayanti, I., \& Ashar, T. (2015). Perbedaan tingkat konsentrasi sebelum dan sesudah adanya bising akibat aktifitas perlintasan kereta api pada siswa di Sekolah Dasar Negeri 067240 Kecamatan Medan Tembung Kota Medan tahun 2015, 18.

Damayanti, M., \& Zuhdi, U. (2017). Pengaruh media scrapbook (buku tempel) terhadap hasil belajar siswa materi keragaman rumah adat di Indonesia kelas IV sekolah dasar. JPGSD, 5(3), 803-812. 
Dewi, R., Rusman, \& Nasir, M. (2016). Penerapan model ARCS untuk meningkatkan ketuntasan belajar siswa pada materi hidrokarbon SMAN 1 Baitussalam. Jurnal Ilmiah Mahasiswa Pendidikan Kimia, 1(4), 87-96. Retrieved from retnowilujeng94@gmail.com

Effendi, M. (2006). Pengantar psikopedagogik anak berkelainan. Jakarta: PT. Bumi Aksara.

Elly, E., Abdulssamad, \& Kresnadi, H. (2013). Peningkatan kemampuan berbicara melalui metode drill pada pembelajaran bahasa indonesia kelas IV Sekolah Dasar Usaba Sepotong. Development, 134(4), 635-646.

Fithria. (2012). Peran keluarga dengan anak retardasi mental di SDLB Negeri Labui Banda Aceh tahun 2012. Idea Nursing Journal, III(2), 42-50. Retrieved from fithria_aceh@yahoo.com

Juniati, E. (2017). Peningkatan hasil belajar matematika melalui metode drill dan diskusi kelompok pada siswa kelas VI SD, 283-291. Retrieved from erlynjuniati12@gmail.com

Kartini, T. (2007). Penggunaan metode role playing untuk meningkatkan minat siswa dalam pembelajaran pengetahuan sosial di kelas V SDN Cileunyi I Kecamatan Cileunyi Kabupaten Bandung. Jurnal Pendidikan Dasar, (8).

Kementerian Pendidikan dan Kebudayaan. (2017). Siswa penyandang disabilitas berdasarkan provinsi. Jakarta: Beitagar.id

Maramis. (2009). Catatan Ilmu Kedokteran Jiwa (2nd ed.). Surabaya: Airlangga University Press.

Merdekawati, D., \& Dasuki. (2017). Hubungan pengetahuan keluarga dan tingkat retardasi mental dengan kemampuan keluarga merawat. Journal Endurance, 2(2), 186-193. https://doi.org/http://doi.org/10.22216/jen.v2i2.1963

Moore. (2004). Handbook of Medical Psychiatry (2nd ed.). Philadelphia: Elserier/Mosby.

Notoatmodjo, S. (2014). Metodologi penelitian kesehatan. Jakarta: Rineka Cipta.

Nuryana, A., \& Purwanto, S. (2010). Efektivitas brain gym dalam meningkatkan konsentrasi belajar pada anak. Jurnal Ilmiah Berkala Psikologi, 12(1), 88-99. Retrieved from denmas_pur@yahoo.com

O’Brien, P. G., Kennedy, W. Z., \& Ballard, K. A. (2013). Keperawatan kesehatan jiwa psikiatrik. (N. B. Angelina, Ed.). Jakarta: EGC.

Ramayumi, R., Nurdin, A. E., \& Nurhajjah, S. (2014). Karakteristik penderita retardasi mental di SLB Kota Bukittinggi. Majalah Kedokteran Andalas, 37, 181-186.

Riskesdas. (2018). Pedoman pewawancara petugas pengumpul data. Jakarta: Badan Litbangkes Depkes.

Riyadi, M. B., Sugiyanto, \& Hidayatullah, M. F. (2017). Physical education as a medium to mentally retarded students' self developments. European Journal of Physical Education and Sport Science, 3(2), 33-49. https://doi.org/10.5281/zenodo.376855

Rohani, T. S., \& Ahmad, I. (2018). Penerapan metode drill bermedia scrapbook terhadap keterampilan berbicara anak tunagrahita, 1-18. Retrieved from trisucirohani@gmail.com

Sari, E., \& Eklesia. (2018). Pengaruh fishing game terhadap konsentrasi anak tunagrahita di SLB C Alpha Wardhana Surabaya, 7(20). Retrieved from ethyca.sari@yahoo.com 
Sartika. (2017). Hubungan peran orangtua dengan tingkat kemandirian activity daily living (ADL) pada anak dengan retardasi mental di Kabupaten Sleman. Journal of Personality and Social Psychology, 1(1). https://doi.org/10.1111/j.14697610.2010.02280.x

Saryono, \& Anggraeni, M. D. (2013). Metodologi penelitian kualitatif dan kuantitatif dalam bidang kesehatan. Yogyakarta: Nuha Medika.

Setiani, A. C. (2014). Meningkatkan konsentrasi belajar melalui layanan bimbingan kelompok pada siswa kelas VI SD Negeri 2 Karangcegak, Kabupaten Purbalingga tahun ajaran 2013/2014. Universitas Negeri Semarang.

Setyaningsih, I. (2017). Metode permainan sensorimotor untuk meningkatkan konsentrasi belajar dengan hambatan kecerdasan kategori sedang. Jurnal Widia Ortodidaktika, 6(6), 601-610. Retrieved from setyaindra28@gmail.com

Sobah., Suherman, A., \& Wiharna, O. (2017). Penerapan metode pembelajaran drill untuk mengatasi kesulitan belajar siswa pada mata pelajaran gambar teknik. Journal of Mechanical Engineering Education, 4(2), 247-255. Retrieved from subhan.faizahhijab@gmail.com

Soetjiningsih, \& Ranuh. (2016). Tumbuh kembang anak (2nd ed.). Jakarta: EGC.

Sularyo, T. S., \& Kadim, M. (2000). Retardasi Mental. Sari Pediatri, 2(3), 170-177. https://doi.org/10.14238/sp2.3.2000.170-7

Swarjana, I. K. (2015). Metodologi penelitian kesehatan (Revisi). Yogyakarta: Penerbit ANDI.

Syahriyanti, Irren, Imron, Ali, Basri, \& Muhammad. (2017). Pengaruh media scrapbook terhadap hasil belajar IPS siswa. Bandar Lampung: PPS FKIP Unila.

Wardani, I. A. K., Astati, Hernawati, T., \& Somad, P. (2008). Pengantar pendidikan luar biasa (1st ed.). Jakarta: Universitas Terbuka.

Wardhani, S. H. (2015). Terapi bermain: cooperative play dengan puzzle meningkatkan kemampuan sosialisasi anak retardasi mental. Jurnal Keperawatan Jiwa. Retrieved from tia4one@yahoo.com

Wardhani, S. W. (2018). Pengembangan media scrapbook pada materi pengelompokan hewan unntuk siswa kelas III sekolah dasar. Jurnal Sekolah, 2(2), 124-130.

Zakarya, Y., Dewi, E., \& Susanto, T. (2016). Pengaruh pelatihan cuci tangan bersih dengan metode bermain puzzle terhadap kemampuan melakukan cuci tangan anak tunagrahita di SDLB-C TPA Kabupaten Jember. E-Jurnal Pustaka Kesehatan, 4(3), 563-567. Retrieved from erti_i.psik@unej.ac.id\%0AAbstract 